\title{
衝擊力による鋼材内のき裂成長開始* (静的予荷重および温度の影響)
}

\author{
前川- 郎**, 田辺裕 治**
}

\author{
The Growth of a Crack in Steel Due to Impact Tension \\ (The Effect of Static Pretension and Temperature)
}

\author{
by Ichiro MAEKAWA and Yuji TANABE
}

\begin{abstract}
The purpose of this paper is to ascertain the mechanical condition and the microstructural aspect of a crack growth in structural steel when an impact load is imposed on it. Impact tensile experiments were carried out using precracked specimens at $77 \mathrm{~K}$. And the effect of superposition static pretension was also examined at room temperature and $77 \mathrm{~K}$. The effect of static and impact stresses on crack growth is discussed, based on the stress intensity factor $\left(K_{1}\right)_{\text {pre }}$ and the dynamic stress $\sigma_{c d}$ at the moment of precrack growth. The summation of boch effects is expressed by $D_{f}$, and it increased with the increase of $\left(K_{\mathrm{t}}\right)_{\text {pre }}$ when static prestress was applied at room temperature. On the other hand, $D_{f}$ decreased with the increase of $\left(K_{1}\right)_{\text {pre }}$ when static prestress was applied at $77 \mathrm{~K}$. In addition, when only an impact load was applied to a specimen, $D$, was smaller for shorter length specimens and for larger values of $a / W$, where $a$ and $W$ are the precrack length and the half width of a specimen, respectively. The size of the plastic region near the prearack tip was measured after fracture, and was independent of the loading type and about three times the grain diameter. The distribution of dislocations near the precrack tip by TEM was observed after fracture. This results showed the different aspects for impact fracture and impact fracture under static pretension.
\end{abstract}

Key Words: Fracture, Impact Load, Static: Load, Steel, Temperature, Stress Waves, Plastic Region, Electron Microscope Observation

1. 緒言

近年の機㭜の高能率化・高速化に伴って, 安全設棓 のために徵揧荷重に対する材料の強度評洒法の確立 がますます急弱になってきている。まだ機械榢動時に おいては不意の衝撃荷重により破壊が起こる場合も节 り得ることでありここのような破壊挙動に対しても基 䂣的知見を得ていく必要があると考えられる。近年， 機械棈造物の破壊に対しては先在き裂がその引き金に なるとする破䁲力学の発展により，き裂の成長および 伝ぱに対寸る力学的条件の研究が進み成果等代てき ている、衡整荷重による破壊に対してもその手法が取 り入れられ，き裂先端の力学的特異性走表与動的㐫力 拡大係数 $K(t)$ の解析およびこれと刘応して锶的破垻

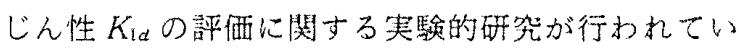
る(1)。この $K(t)$ の算出にあたつては荷重条件ならび に境界条件が簡単化されているが，棈造物においては 境界での複雑な応力波の反射・透過举動が起こるため 実際の適用にあたってはこのことについての検澍が必

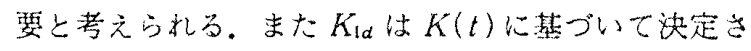

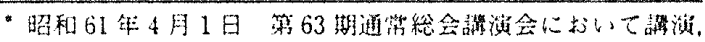

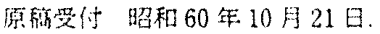

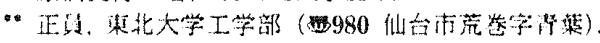

れるので組織敏感をき裂先端微小領域内の現象を反映

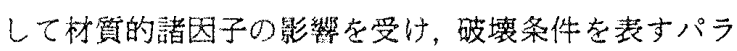
メータとして用いるに岾それらとの関連性を明らかに ナる必舜が岕ると教えられる。そこで著者らは洗に 炭䋜鈯の予き裂付き試験片を用いて低温下での衝盤引 張破壊奏験を行い，力学的には応力波形の特性を表す パラメータによって検討し，材䝷的には電顕およびX 線による破面钼察ならびに転位分布の観测等を行って

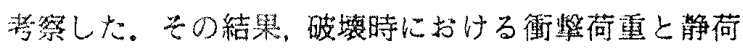
重の関保を明らかにした。また衙紫破壊では予き裂先 端での䎐位分布も含めた微視的変形举動が静荷重に上 る破墩の場合とは翼なっていた。本報ではさらに破境

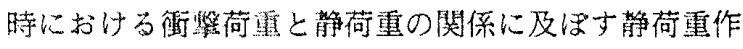

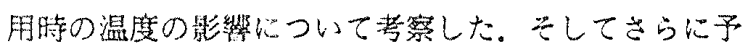
き裂先端ての塑性域大ききや微視組織に注目してその

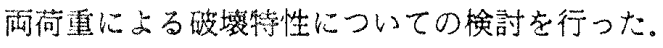

\section{2. 実 験 方 法}

供武材は市販のSS 41, 带板材である。図1に試験片

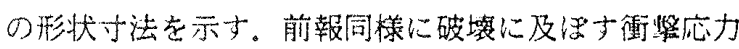
の波動効果を明らかにするために，試験片長さには同 图に示す 3 種頑のものを用いた。試駼片は切久きから

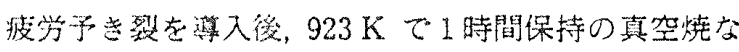


ましを行ったのち実験に供した。焼なまし後の供試材 の機械的性質を表 1 亿，顕微鏡組織を図 2 にそれたれ 示文。平均結晶粒径は $10 \mu \mathrm{m}$ で岕った。

実験装置ならびに実験方法の詳細は前報 ${ }^{(2)}$ と同様で

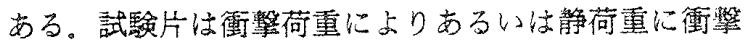
荷重后畳して作用きせて破断させた。破断時の荷重 条件仙き裂成長開始点の応力で表すことにして, 静荷

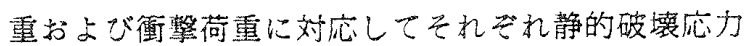

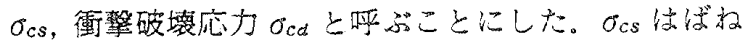

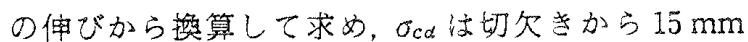
離れた試験片中央上にひずみゲージを貼っててれより

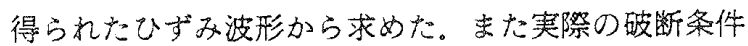

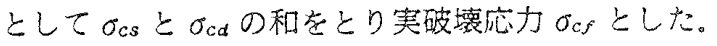

\section{3。笑驗緢果と考察}

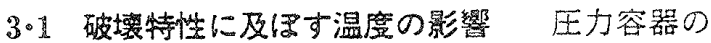
耐圧試験に関連する問題しして，低温で破壊じん性試 験を行う際に予荷重履歷が破浐じん性 $K_{c}$ に影響を及 ぼすことが報告されている(3) (5)。本報では破壊に対す

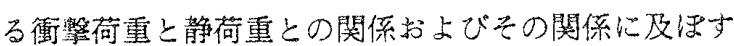
温度の影響を明らかにするため，静荷重を与える際の 温度を变えて奏験を行い检討してみた。

室温で静荷重を与えた後液体窒罢で $77 \mathrm{~K}$ に冷却し 衝慗破断させた場合をケース I，77 K で静荷重を与 えた後ただちに衝慗破断させた場合をケース 2 として 結果を図 3 に示す。いずれの試娩片長さに対してもケ 一ス1では $\sigma_{C S}$ の增加に伴い $\sigma_{C \beta}$ も增加するが,ケ一

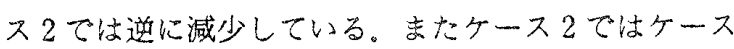
1に比べて全体的に $\sigma_{c f}$ が大きくなっている。これは 図中のき裂長さ比 $a / W$ 值 $(a$ : 予き裂長さ， $W$ : 試跧

表 1 供試材の静的㙨械的性筫（室温）

\begin{tabular}{|l|c|c|c|}
\hline $\begin{array}{c}\text { Yield } \\
\text { Strength } \\
\sigma_{y s}\end{array}$ & $\begin{array}{c}\text { Tensile } \\
\text { Sirengih } \\
\sigma_{B}\end{array}$ & $\begin{array}{c}\text { Elongation } \\
\text { (GL }=50 \mathrm{~mm}) \\
6 \%\end{array}$ & $\begin{array}{c}\text { Reduction } \\
\text { of Area } \\
\psi \%\end{array}$ \\
\hline $26 \angle \mathrm{MPa}$ & $315 \mathrm{MPa}$ & 40.6 & 34.8 \\
\hline
\end{tabular}
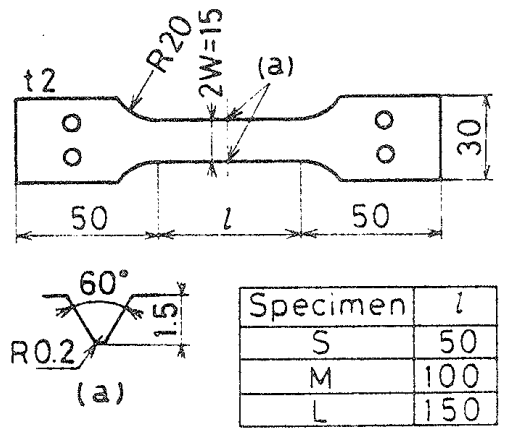

図 1 試験片
片半幅）に示すように，洎入した予き裂長さが両者こ 異なって扮りケース2の活うが短かっただと考えら れる。そこでこの関係を定性的に明らかにする都合上，

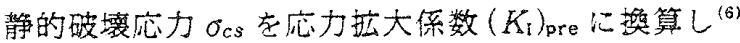
また衙揧破境応力 $\sigma_{c \alpha}$ 当同様な表式として $\sqrt{\pi a} と の$ 䅡们置き換えて $D_{f}=\left(K_{\mathrm{I}}\right)_{\mathrm{pre}}+\sigma_{c a} \sqrt{\pi a}$ とし, 図 3 を 整理し直してみたものを図4に示す。磁密にいえ代 $\sigma_{c d}$ 応力拡大保数に換算することに法緒言で述べた ように問題がある。また同図に级室温と77Kでの静 荷重のみによる場合の実駼結果もそれぞれ $\left(K_{c}\right)_{R . T}$ ， $\left(K_{c}\right)_{77 \mathrm{~K}}$ として示した。

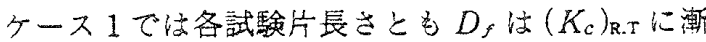
近する形で $\left(K_{\mathrm{I}}\right)_{\mathrm{pre}}$ の增加に伴い増加している。ケ一 ス 2 では $D_{f}$ は試験片長さによらず $\left(K_{C}\right)_{77 \mathrm{~K}}$ に澵近す る形で $\left(K_{1}\right)_{\text {pre }}$ の增加に伴って減少しており，ケース 1とは逆の傾向にある。また車ケースとも S 試験片の 結果のばらつきが大きい。これは試験片長さが短いた めに多数の反射応力波により測定される応力波形が複

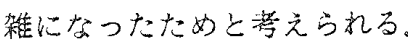

さらに両ケースの相反する特性の差は $\left(K_{\mathrm{i}}\right)_{\mathrm{pre}} \geqq 3$ $\mathrm{MPa} \sqrt{\mathrm{m}}$ で現れているのてここの点につき走查電䫓に

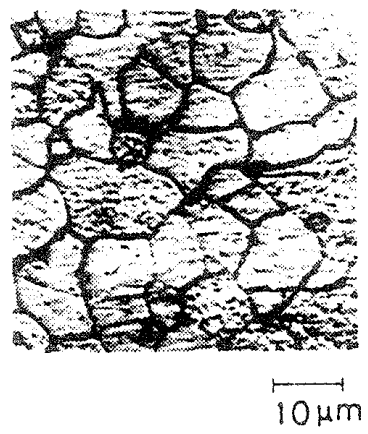

図 2 供試材の顕微鏡組織

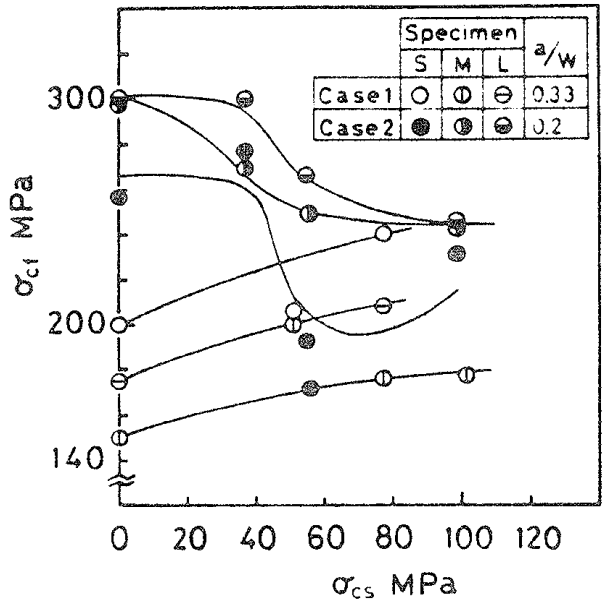

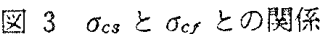


よる破面鋧察を行って検討してみた。その破面写真例 を而ケースのL 試験片について図 $5(\mathrm{a}),(\mathrm{b})$ に示 す。予き裂先端の試験片厚さ中央付近を撮影したもの であるが(a)のケース1では予き裂とへき開破面との 間にストレッチソーン状のものが存在している。この 結果杖 $\left(K_{\mathrm{I}}\right)_{\mathrm{pre}} \geqq 3 \mathrm{MPa} \sqrt{\mathrm{m}}$ に括ける他のケース 1 の 試験片について同様に見られたが，ケース2ては（b） に示すようにそのストレッチゾーン状のものは観祭さ れなかった。このことからケース1では室温で静何望 を与えたことにより予き裂先端が鈍化し続いて与えら れる衝揧荷重による応力集中を緩和方るが，ターース 2 ではこのような応力集中の緩和は起こりにくいと考え られ，之の結果上述のような両ケースの特性が得られ たものと考元られる。

さらに図 $4 て\left(K_{\mathrm{p}}\right)_{\mathrm{pre}} \leqq 3 \mathrm{MPa} \sqrt{\mathrm{m}}$ について兒ると 両ケースとも試験片長さlの短いものほど $D$ が小さ い傾向に市る。特に $\left(K_{1}\right)_{\text {pre }}=0 \mathrm{MPa} \sqrt{\mathrm{m}}$ の衝慗破壊 の場合にその傾向が著しい。これは前報における衝慗

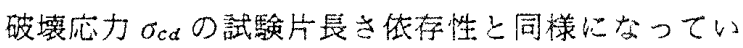
る(2)。さらにケース2のほうがケース1より全体的に

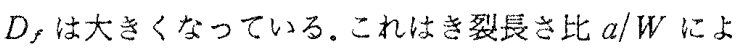
り予き裂先端における弾性広力波の回折ならびに散乱 による応力集中への奇与が異なり， $a / W$ 值が大きい ものほどその効果が大きくなるためと考えられる。こ のように衝杽破裴の場合には一定荷重であっても波動 の効果のため試験片長さ $l$ や裂長さ比 $a / W$ に上り 強度が翼なってくる場合があるのでこの点留湆すべき 特性である。

以上の上うに衝慗荷重と静荷重とが重祭して作用す る場合の破壤特性は静荷重を与える時の温度が異なる と大きく翼なることがわかった。特にここでは低温で 静荷重を与元た場合に强度が低下しており，安全工学

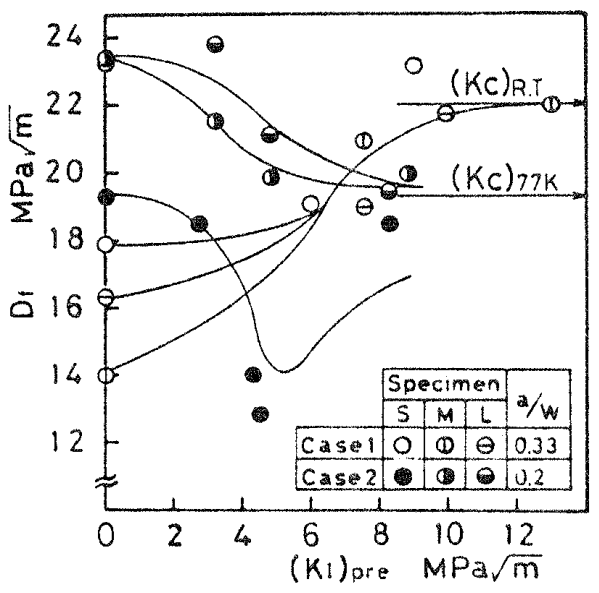

図 4 D, と $\left(K_{1}\right)_{\text {pre }}$ との関係
上注意が必要てある。

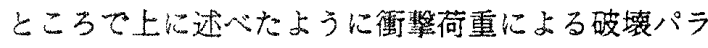
メー夕を $\sigma_{c d} \sqrt{\pi a}$ にると応力波の特性を含めるこ亡

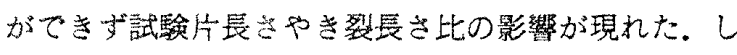
たがって強度心対する静荷重と衝撃荷重との力学的等 価性を定舅的に議詅する䟢に間题となる。一方，强度 虹微視的レべルでの材料挙動により決定されると考え られるので破霓パラメータについては巨視的な力学的

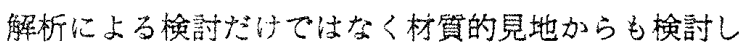
ていく必要が岁ると考元られる。また微視的な立場か ら格討を進めて巨視的な力学的特性を理解すること は，特に本報におけるような静荷重と衙慗荷重といっ た力学的に注翼なる形の荷重による破壊についての知 胃を得るために沈効であると考えられる。そこで車 荷重の力学的等価性に対して考察を行っていくた如 透過電影による諸観察を次に行ってみた。從来, 疲労

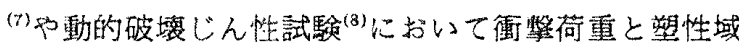
を関連させた挎察が行われており，また前報の結果て はぜい性破塤であっても衝慗荷重と静荷重とでは予き 裂先端の微視的変形挙動が異なっていたことから本報 で结子き裂先端の塑性域大きさや微視組織に注目して 栲察立行った。こーではケース1の試験片について観 察を行った結果について述べる。

\section{$3 \cdot 2$ 予き端先端のすべり線および転位}

$3 \cdot 2 \cdot 1$ 予瑟先端の塑性域大きさの測定 塑性 域内でのすべり線や転位の観繁を行うには塑性変形の

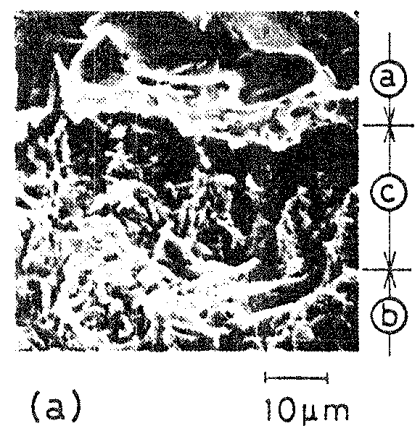

[Case 1]

$D_{f}=21.5 \mathrm{MPa} \sqrt{\mathrm{m}}$

$\left(K_{I}\right)_{\text {pre }}=9.9$. (a) Cleavage
fracture

(b) Fatigue precrack

(C) Stretched zone

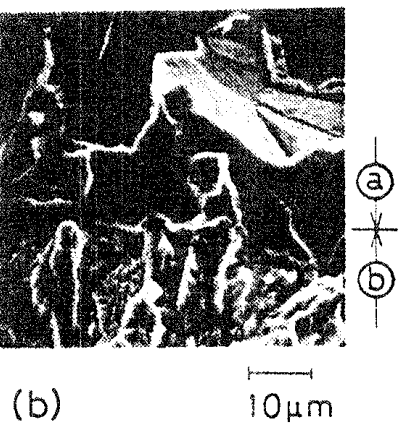

[Case 2] $D_{f}=21.1 \mathrm{MPa} \sqrt{\mathrm{m}}$ $(\mathrm{KI})_{\text {pre }}=11.8$ "

(a) (a) Cleavage fracture

(D)Fatigue precrack

图 5 破面の SEM 写真例（L 試駼片） 
生じている籍再を求めておくことが必要である。また このこと法微視組織と巨視的力学量との関連性を検討 する上ても重要てある。そこでまず破断した試験片の 表面での予き裂先端の塑性域大きさを測定した。試験 片は図 3 に执いて示したケース1の $\sigma_{c s}=0 \mathrm{MPa}$ の衛 撃荷重だけを受ける場合と $\sigma_{c s}=77 \mathrm{MPa}$ の衝揧荷重 と静荷重の重畳した荷重を受ける場合とを取り上げ た。まず硬度測定による塑性域大きさの実測を試み だ(9)。本実験のようにぜい性破壊を起こしている場合 に注塑性変形域はごく破面近くに限定されるた如超微

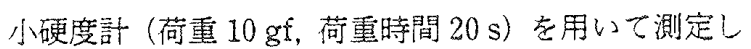
た。本硬度計による圧痕の大きさは約 $10 \times 10 \mu \mathrm{m}$ であ つたので漂は1結晶粒大きさ单位での硬度測定ができ たものと考えられる。各試験片長さについて測定しだ その結果を図6，図7に示す。測定は図中に示す $X, d$ 方向に沿って行った。硬度の測定值Hvは試龊片によ り若干買なるので試験片ごとに破断の前後で硬度変化 のない破面加ら $2 \mathrm{~mm}$ 離机た点での值 $\left(H_{V}\right)_{d=2.0}$ で見 準化し， $\Delta H_{V}=H_{V} /\left(H_{V}\right)_{d=2.0}$ として示してある。この $\Delta H_{V}$ の急增点 $d=d_{p}$ が塑性域大きさ $d_{0}$ に対応する と考えられる。図 6 に示方衝等のみによる破渐の場合

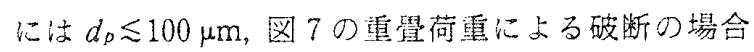
には $d_{p} \leqslant 50 \sim 150 \mu \mathrm{m}$ と推定できる。しかし荷雷形式 による塑性域大きさの明りょうな差は見られない。ま た $\Delta H_{V}$ の急增点もあまり明りょうで洁ないためこの 方法だけからd。正確に決定するの注困難であると 考えら机る。そこで次に塑性域の平面的应広がりも含 めて破面近傍を精度上く稪察測定できる万法として干 涉䁰微鏡を用いた測定を行ってみた。

図 6，図7て硬度测定を行ったのと同じ試験片表面 の破面近くで干涉影微鏡写真を撮影し塑性域の大きさ を測定した。図 8 に卡の写真例を示す。図中に示すよ うに試験片表面の凹凹により干涉じまが屈曲するので

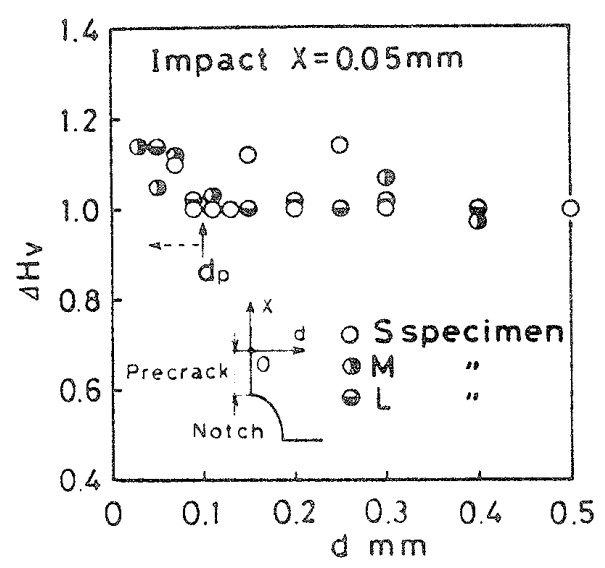

図 $6 \Delta H_{V}$ の測定結果 $\left(\sigma_{c s}=0 \mathrm{MPa}\right)$
破面からその届曲点までの距離 $d=d_{p i}$ を測定して塑 性域大きさ $d_{p i}$ とした。志た予き裂先端から $X$ 方向人 の距離による変化を見るために $X=0.05 \mathrm{~mm}, X=$ $0.3 \mathrm{~mm} の 2$ 筒所で测定した。るその結果を試験片長さ にに対して整理してみたものを図 9 に示す。全体的に 干涉顥微鏡による $d_{p i}$ 洼硬度测定による $d_{p}$ の約 $1 / 3$ 程度となっている。これは破面縁ては著しい塑性変形 を受け凹凹主激しいことを意味して拉り，この部分で 干涉じまの变化が特に明りょうに現れたためと考えう れる。衝慗のみによる破断の場合に泣試駼片長さしが 長いものほど $d_{p i}$ は大きくなりその傾向快子き裂先端 からの距雒 $X$ が大きいほど著しい。重畳荷重の場合に

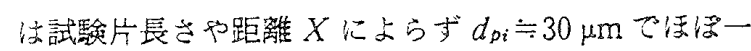
定となっている。しかし衝揧のみによる破断の $X=$ $0.3 \mathrm{~mm}$ の場合を除いて $25 \leqq d_{D i} \leqslant 35 \mu \mathrm{m}$ の範囲にあ り塑性域大きさは荷重形式や試験片長さに上らず结涩 一定とみなしてよいと考えられる。この結果は衝揧速 度が $2 \mathrm{~m} / \mathrm{s}$ 程度の場合のものであり, また重覺荷重に よる破断試験片注 $\sigma_{c s}=77 \mathrm{MPa} の 1$ 種類に測定考限 つたが，原的の大きによっては尒き裂先端の鈍化の 影響が現れ塑性域大きさにも影響すると考えられるの

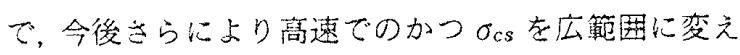
て検討を行うことが必要であろう。一方，衙整のみに

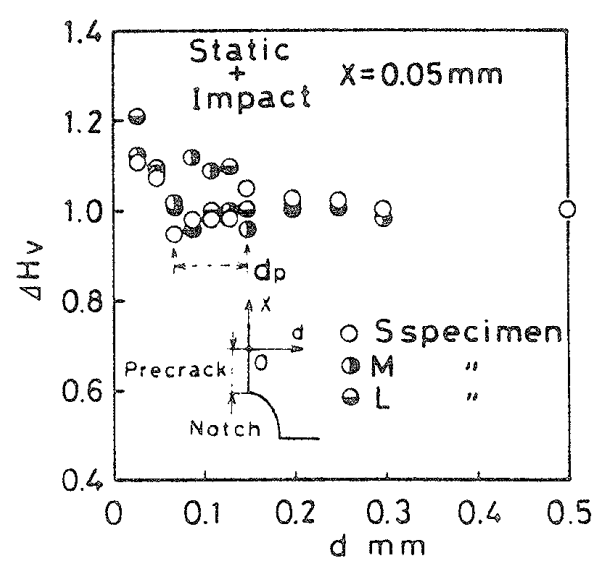

図 $7 \Delta H_{V}$ の測定結果 $\left(\sigma_{c s}=77 \mathrm{MPa}\right)$

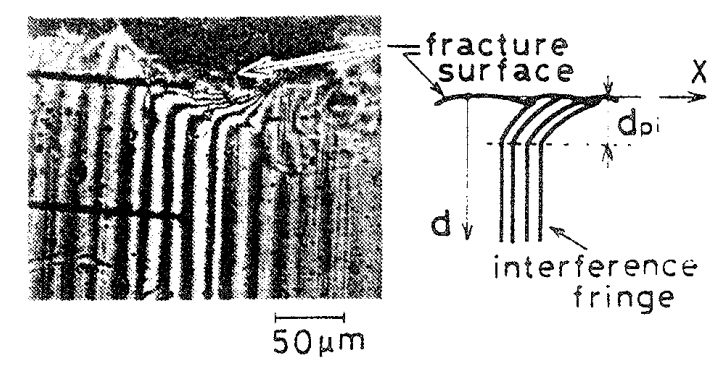

図 8 干涉影微鏡写基例 
よる破断の $X=0.3 \mathrm{~mm} の$ 結果は予き裂先端より少 し離れた所のものであるので進展き裂の影響を受け， 試験片長さに上りその進展速度が翼なったためと考え られる。すなわち進展き裂先端の応力場はき裂進展速 度の影響を受けこの場合も応力波の挙動を考澢する必 要がある(10)ので，この点についても今後さらに检討を 加えたい。

以上のことから本実験範囲では塑性域大きさは荷重 形式や試験片長さによらずほほ定で2 3 結晶粒大 きさ程度てあると考えられる。このように蜆的な量 としての塑性域大きさ濐熬荷重による破壤の場合も

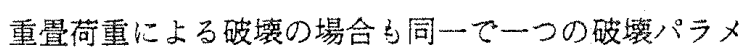
一夕になり得るが強度は組織敏感な物性であり微視組 織に基づく考察が必要である。そこで次に試䮖片表面

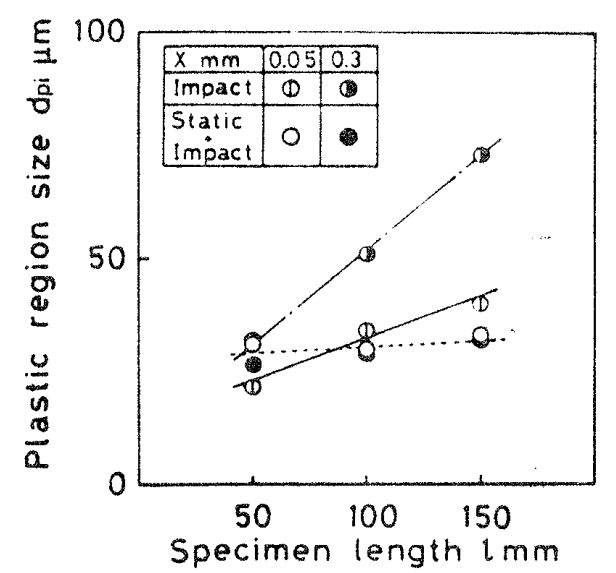

図 9 干涉䫓微鏡による熋性域大きさの測定結果
の塑性域内のすバり線の筧察を行った。

$3 \cdot 2 \cdot 2$ 破面近傍のすべり線破面縁から二段レ プリカ法により試料作製して透過電顕写真を撮影し

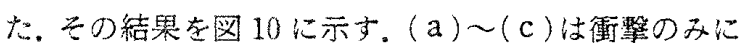
上る破断，(d)〜(f)は重嘼荷重による破断の場合で 茄る。いずれも方べり線怯破面加らd方向に $10 \mu \mathrm{m}$ 程 度の簕国内で観祭された。（a)〜(c)では概して平行 で段差の小さなすべり線となっている。(d)〜 ( f )で 流段望の大きなすべり線の中に細かなすべり線が見ら れるが、これは（a)〜(c)との此較から, 最初の静荷

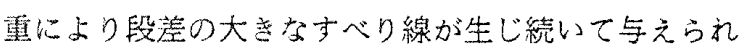
た衡慗荷重に上り緗かいすべり線が生じたものと考兄 られる。また（a)ー（c）ではすべり線の間隔泣試験片 長さの短いもの弫よ゙小さい傾向が見られるが(d)

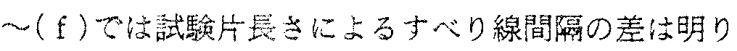

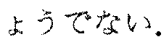

このようにナべり線の形態から見ると荷重形式によ り若干の差が見られた。このような差異には材料内部

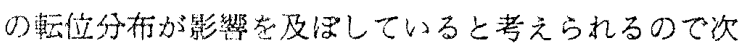
に破面䦽下の転位方布についての観察を行ってみた。

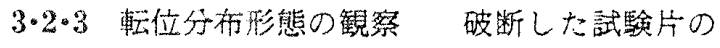

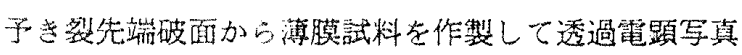
を撮影した。その結累を図11に示す。ここでは衝慗の みによる破断については M 試験片に対して，重悬荷

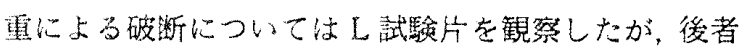
の場合に流図 9 に和した塑性域大きさも図 10 に示し

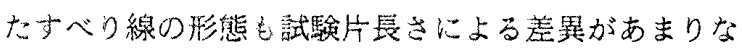
いので荷重形式による転位分布の相違を考察するには
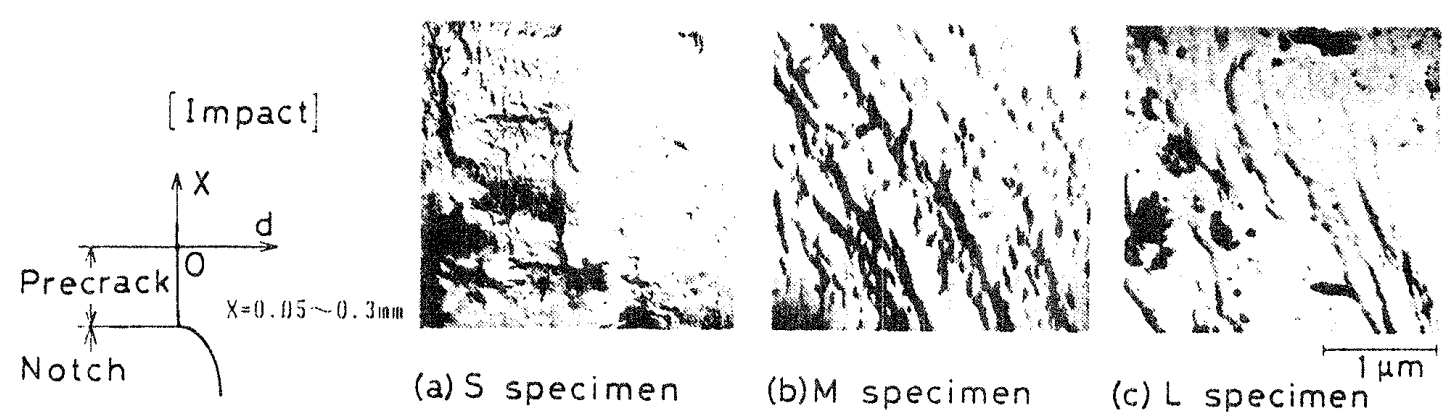

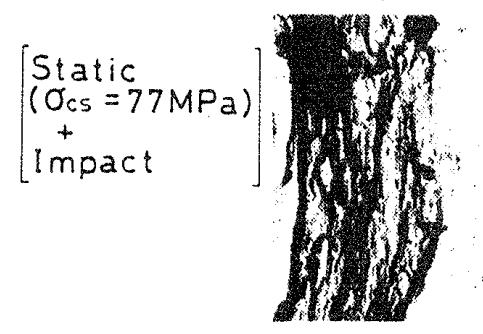

(d) S specimen

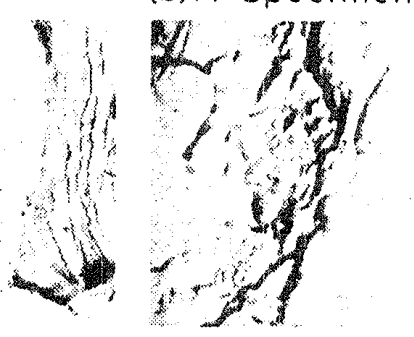

(e) M specimen (c) L specimen

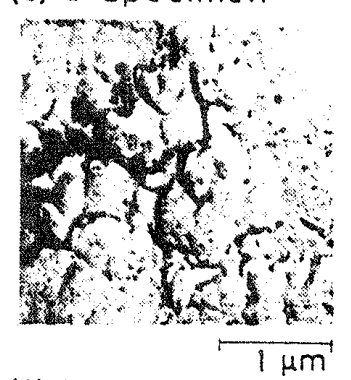

(f) $L$ specimen

図10破面近傍のすベり線 


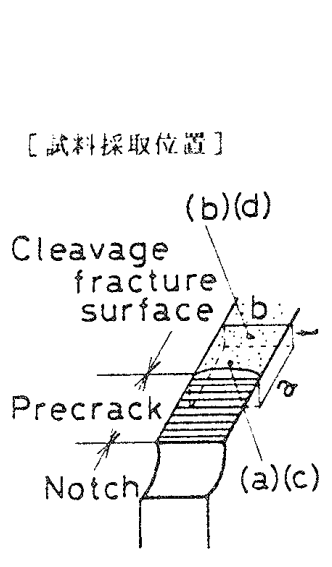

$a \times b \times t=3 \times 2 \times 0.2 \mathrm{~mm}$

\section{[impact]}

\section{Mspecimen}

$(b=100 \mathrm{~mm})$

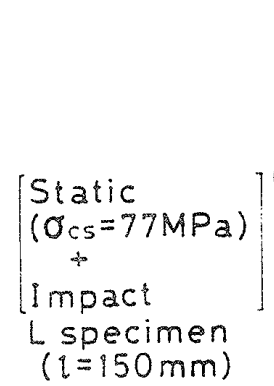

(a)

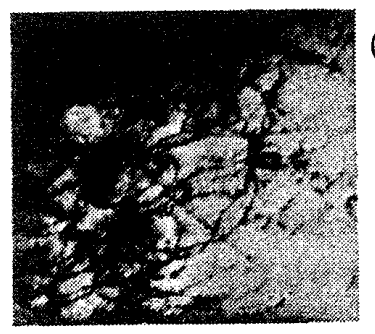

(c)

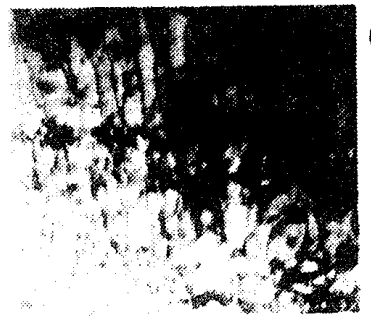

(b)

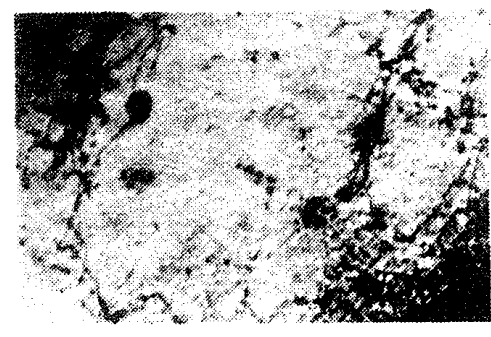

(d)

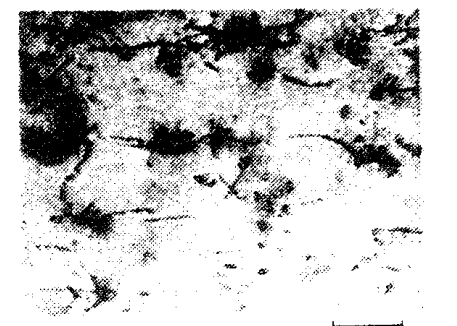

$\overparen{0.2 \mu \mathrm{m}}$

図 11 破面面下の䎐位分布形態

問題がないと考えた。予き裂先端心近い（a)，(c)の

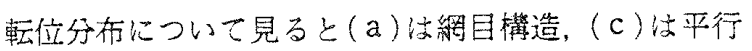
で比較的一様な分布となっでりをれをれ前報におけ る衝揧引張り坊よび静引張りの結果と対㐫してい る(2)。このことから本実験範国における重瞕獄重によ る破断の場合には静荷重作用後与えられる衙繁荷重注 䎐位分布にあまり影響を及ばさないるのと考えられ 万。次に予き裂先端加踓れた（b），(d)について胃 ると闻者汇頙著な差はなく転位も予き裂先端に比べて 少なくなってらり，予き裂先端に比べてよりぜい性的 な破壤が起こったものと考えられる。以上のように茼

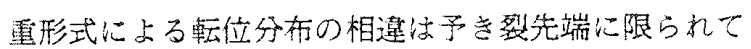
現れており，重覺荷重による破断では䋖荷重による破 断の転位分布に類似していな。この結果は衙整速度の 大きくない破面直下のものなので今後はさらに高速荷 望の場合や哚い場所に対する研究が望まれる。

\section{4。結言}

以上の結果をまとめると次のようになる。

（1）衙慗荷重と静荷重とが直胃して作用方る場合

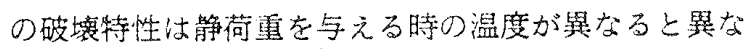
り，强度を表すパラメータとして D，を用いて倹討し た結㬎， $77 \mathrm{~K}$ で静荷重を与えた場合には静荷重の增 加に伴い $D_{f}$ が低下した。

（2）衡紧のみによる破壊の場合には一定荷重下で

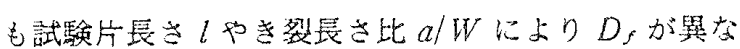
り，にの短いほどまだ $/$ /W の大さいどその倠が低 下した。
本実験の董揧速度は比較的低速であったため，より 高速の場合に峙棣相が必ずしも同一でなくなることも 考虑して微視的観察を行った結果, 本案験範国では

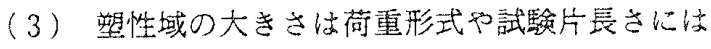
関倸せず结保一定で破面から 2 3 結晶粒大きさ程度 に達していた。

（4）破面近くの試験片表面ですべり線の観察を行 つた結果，衝整のみによる破断では平行で段差の小さ なな゙゙り線が見られ，重畳荷重による破断では段差の 大きなず゙り線の度に細かい方べり線が見られた。

（5）破面直下の転位分布形態を籍祭した結果，荷 重形式による分布の相薏は予き裂先端で現れてかり， 衙絮のみによる破断では網目棈造に，雷量荷重による 破断では静荷重による場合に類似した平行で比較的一 様な分布となっていた。

終わりに本研究に牥昭和 59 年度文部省科学研究費 の御援助をいただいだ。ここに記して謝意を表する。

$$
\text { 女 献 }
$$

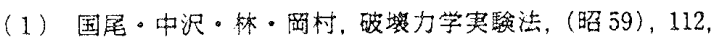
朝會艁店。

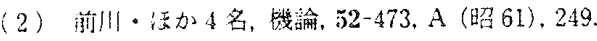

（3）越賀，日本造船学全論文集，127(昭 45)，239.

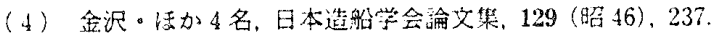

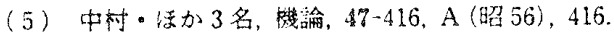

（6）文献(1)の 240 ページ.

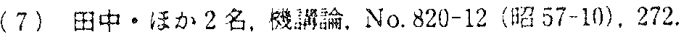

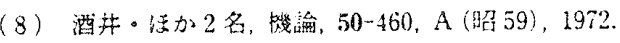

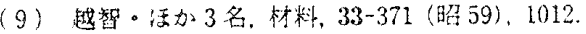

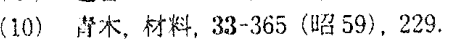

